Hydraulic Engineering Repository

Ein Service der Bundesanstalt für Wasserbau

Newhouse, Scott

\title{
Earth Dam Failure by Erosion, A Case History
}

Verfügbar unter / Available at:

https://hdl.handle.net/20.500.11970/100305

Vorgeschlagene Zitierweise / Suggested citation:

Newhouse, Scott (2010): Earth Dam Failure by Erosion, A Case History. In: Burns, Susan E.; Bhatia, Shobha K.; Avila, Catherine M. C.; Hunt, Beatrice E. (Hg.): Proceedings 5th International Conference on Scour and Erosion (ICSE-5), November 7-10, 2010, San Francisco, USA. Reston, Va.: American Society of Civil Engineers. S. 348-357.

(c) (1) 


\title{
Earth Dam Failure by Erosion, A Case History
}

\author{
Scott Newhouse ${ }^{1}$, P.E., M.ASCE
}

${ }^{1}$ Senior Engineer; Bechtel Power Corporation, 5275 Westview Drive, Frederick, MD 21703

\begin{abstract}
In January, 1998 the Archusa Creek Dam failed by breaching through its

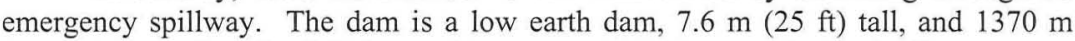
$(4,500 \mathrm{ft})$ crest length. It is located in southeast Mississippi, in Clarke County, near the town of Quitman. At the time of its failure, the dam had a concrete ogee weir for a principal spillway, and a vegetated earth emergency spillway. (Spillway configuration has been modified since the failure.) The impounded lake is a stateowned water park, used solely for recreation. Fortunately, the dam is a low hazard structure. The Chickasawhay River is less than $0.4 \mathrm{~km}(1 / 4 \mathrm{mi})$ downstream of the dam. The dam is in the flood plain of the river; accordingly, there is little development downstream. Consequences of failure were mostly limited to the loss of the water park.

The dam failed during a rain storm corresponding to approximately a 5 year return period. The failure was triggered by intense rainfall of near $10.8 \mathrm{~cm}$ (4.25 in.) falling in just a few hours over the watershed. The watershed is very large compared to the size of the reservoir; the ratio of watershed area to lake surface area exceeds 50:1. Consequently, such a storm event results in very high inflow to the reservoir. Runoff generated by the storm caused a rapid rise in lake level to elevation above the flood pool, resulting in flow over both the principal and the emergency spillways. A breach formed through the emergency spillway due to erosion. The failure mechanism is an established, well known one, of progressive erosion and headcutting due to excessive water flow velocity.

By modern design standards, the dam should have sustained this storm event without incident. Modifications to the dam made in 1994 set the stage for failure. The paper evaluates these modifications, along with the dam's design and specific features and factors that led to failure.
\end{abstract}

\section{INTRODUCTION}

Archusa Creek Dam was built in 1971. Figure 1 illustrates the location of the dam, near Quitman, Mississippi. A state agency owns the lake and dam; it is used exclusively for recreation (operation of a water park). The lake is shallow, with

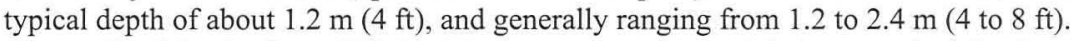

The lake is about 172 ha ( $425 \mathrm{ac})$. Size of the lake's watershed is about 15,800 ha $(39,000 \mathrm{ac})$, resulting in significant in-flow to the lake during storm events. There is little storage volume available in the lake compared to in-flow; consequently, the dam must pass nearly all in-flow.

The lake is in the flood-plain of Chickasawhay River. A high river stage produces tail-water below the dam that often exceeds the lake elevation. 


\section{DAM DETAILS}

The dam is built of compacted earth fill with a maximum height of $7.6 \mathrm{~m} \mathrm{(25}$ $\mathrm{ft}$ ) and a length of about $1370 \mathrm{~m}(4,500 \mathrm{ft})$. The dam is homogenous, with no internal seepage control and no foundation cut-off. Fill material for the dam is generally fine silty sand, as this soil was locally available for construction.

In the 1980s the principal spillway was fitted with an inflatable gate; this configuration was modified in 1994 due to ongoing problems with maintenance and vandalism. In 1994 the spillway was modified with an ogee crest and series of sluice gates through the ogee. The crest and the gate inlets were all fitted with fish retaining screens.

For passing in-flow exceeding the principal spillway capacity, the dam was designed with an uncontrolled emergency spillway, with vegetated earth surface/lining. During the 1994 modification, the emergency spillway was widened from $120 \mathrm{~m}(400 \mathrm{ft})$ to $300 \mathrm{~m}(1000 \mathrm{ft})$. It was again modified shortly before the 1998 failure with the excavation of a drainage ditch within the spillway to facilitate rapid drainage of flood water from lake-side residential yards. This later modification contributed to the dam breach by initiating erosion in the emergency spillway. Notably, the fish retaining screens clogged with debris during the failure storm and contributed to breaching by restricting spillway capacity.

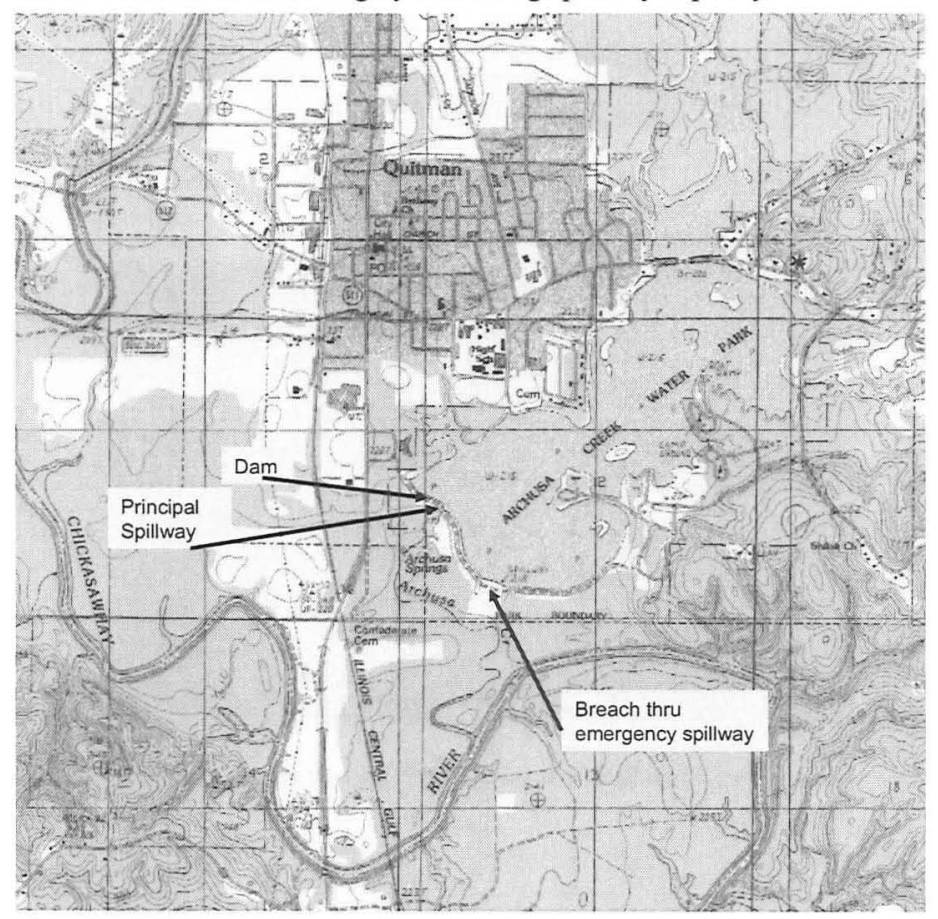

Figure 1. Location map (source map USGS Quitman, Miss. Quadrangle, 1983). 


\section{DETAILS OF DAM BREACH FAILURE}

The breach formed by erosion of soil within the vegetated earth emergency spillway due to high discharge velocity which the spillway surface could not sustain. Figures 2 and 3 illustrate the position of the breach within the dam. The storm causing the failure was an event corresponding to a 5 year return period. Rainfall from this storm was nearly $16.5 \mathrm{~cm}$ (6.5 in.) in a 3 day period. However, the dam's failure was preceded by intense rainfall of $10.8 \mathrm{~cm}$ (4.25 in.) over a period of only a few hours.

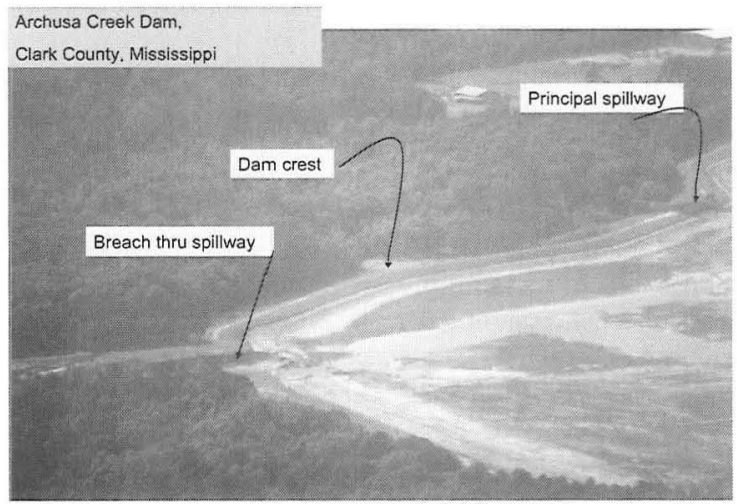

Figure 2. Breach through emergency spillway.

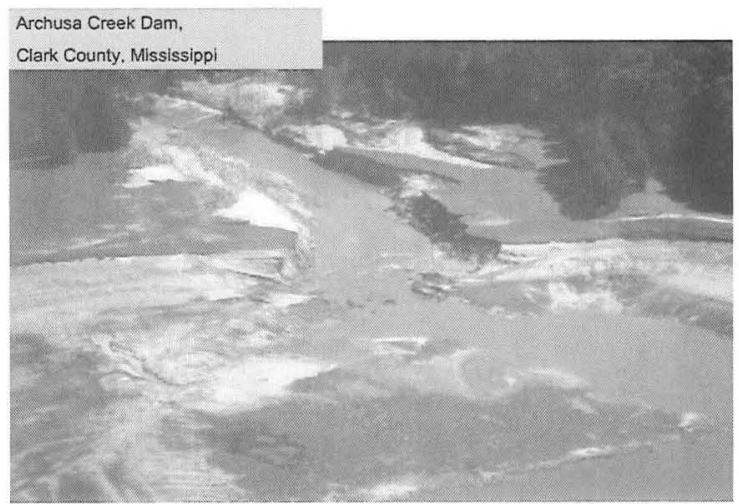

Figure 3. Close-up view of breach. 


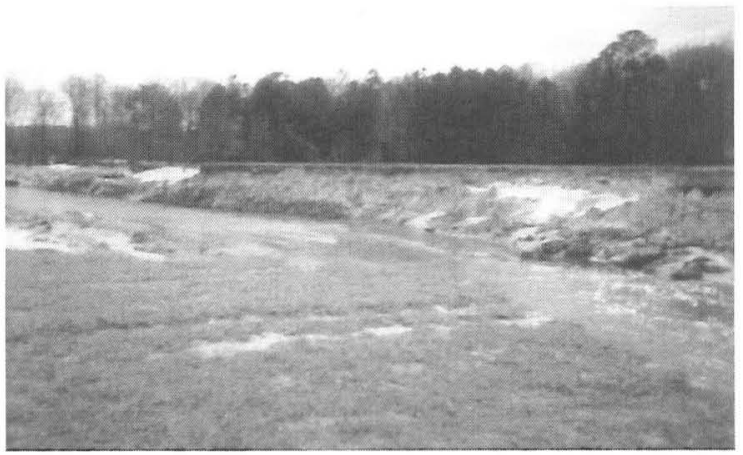

Figure 4. Breach through emergency spillway showing grass surface.

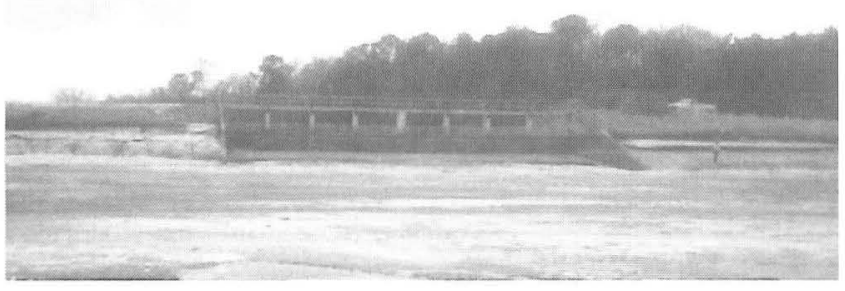

Figure 5. Photo illustrating principal spillway and typical depth of lake.

\section{Emergency Spillway Operation}

Analysis shows that the emergency spillway would activate with a storm corresponding to a 2 year return period. Consequently, the emergency spillway was subjected to frequent flow. Hydraulic analysis indicates that flow in the emergency spillway in the 1998 failure storm was $200 \mathrm{~m}^{3} / \mathrm{s}(7,000 \mathrm{cu} \mathrm{ft} / \mathrm{s})$, with a velocity exceeding $1.5 \mathrm{~m} / \mathrm{s}(5 \mathrm{ft} / \mathrm{s})$.

\section{Erosion Mechanism}

NRCS and USACE design references establish a range of velocity that a vegetated earth spillway can sustain. Federal Energy Regulatory Commission (FERC) (2003) tabulates sustainable velocity listed in applicable NRCS and USACE design guide documents, as excerpted below, in Figure 6. The NRCS document establishes a typical sustainable velocity in the range of 0.6 to $1.5 \mathrm{~m} / \mathrm{s}(2$ to $5 \mathrm{ft} / \mathrm{s})$, depending on the base soil and the grass type. Maximum sustainable velocity (atypical) is about $2.4 \mathrm{~m} / \mathrm{s}(8 \mathrm{ft} / \mathrm{s})$ for a non-erodible soil and specific Bermuda species of grass. 
Table III-3

Yosimun

US Army Corpe of Engineers, EMf $1110-2-1601.1001$

\begin{tabular}{|c|c|}
\hline Chanuel Material & Ifean Channel Velocitr: (ft serc) \\
\hline Fue Sand & 20 \\
\hline Cosrse Sand & 4.0 \\
\hline Fine Gravel & 60 \\
\hline Eartb-Sandy Silt & 20 \\
\hline \multicolumn{2}{|l|}{ Grass-lined Eurth: (stopes less than 5\%) } \\
\hline Bermuda Grass on Sandy S th & 60 \\
\hline Kentuciry Blue Grass ca Sandy Silt & 50 \\
\hline
\end{tabular}

The US Nirural Resource Conservation Service (XPCS) (formerly the US Soil Consermtion Service) provides masimum permissible relocities for channels lined with grass. The NRCS maximum permissible velocitis for the relevant slope range are summarized on Table IIIbelow.

Table III-4

Jaximum Permissible Velocities for Grass Linet Chaunek

(C) vatural Resource Couservation Sertice, Sottrce: SCS 1055. Table 7-1)

\begin{tabular}{|c|c|c|c|}
\hline \multirow[b]{2}{*}{ Irpe of cover } & \multirow{2}{*}{$\begin{array}{c}\text { Slope Range } \\
\text { (percent) }\end{array}$} & \multicolumn{2}{|c|}{ Permissille Velocits (ft sec) } \\
\hline & & Erocton-testrtant seils & Extily eroded solls \\
\hline Bermuda Grass & $0-5$ & 8 & $\theta$ \\
\hline Fuffalo graxs Kratuchy bluegrass & 0.5 & 7 & 5 \\
\hline \begin{tabular}{|l|} 
Sod-fomming grass maxnares \\
\end{tabular} & $0-5$ & 5 & 4 \\
\hline \begin{tabular}{|l|} 
Other grasses \\
\end{tabular} & $0-5$ & 35 & 25 \\
\hline
\end{tabular}

Figure 6. Range of sustainable Velocity on Vegetated Earth Surface (from FERC (2003)).

The fine silty sand soil used as fill in the emergency spillway has a low resistance to erosion. According to the criteria in Figure 6, maximum sustainable velocity on the Archusa Creek Dam's emergency spillway is $0.8 \mathrm{~m} / \mathrm{s}(2.5 \mathrm{ft} / \mathrm{s})$. Based on calculated velocity during the 1998 failure storm near $1.5 \mathrm{~m} / \mathrm{s}(5 \mathrm{ft} / \mathrm{s})$, erosion through the spillway material would have been expected. The calculated velocity is based on the broad flat spillway; the ditch excavated into the emergency spillway would have resulted in velocity exceeding $1.5 \mathrm{~m} / \mathrm{s}(5 \mathrm{ft} / \mathrm{s})$.

The specific erosion mechanism is illustrated and explained by Seed et al (2006). This group extensively studied the soil erosion process in levee over-topping after the Hurricane Katrina disaster in New Orleans. The work by Seed et al is not specifically applicable to vegetated earth spillways. But the erosion principle for soils is the same in the levee study and in the case of the dam spillway. Results of the New Orleans levee study match with the specific events on the dam spillway, the erosion of a fine sand soil. The levee study parameters for velocity and critical shear stress apply to a bare soil without vegetation. For the dam spillway, once the vegetation was lost during the breach event, the resulting bare soil was then similar to the study condition.

Figure 7 illustrates that fine silty sand soil within the dam's emergency spillway is generally the most easily eroded soil category, and that erosion will result in this soil at a shear stress of about $0.1 \mathrm{~N} / \mathrm{m}^{2}$, the minimum for all soil types. 


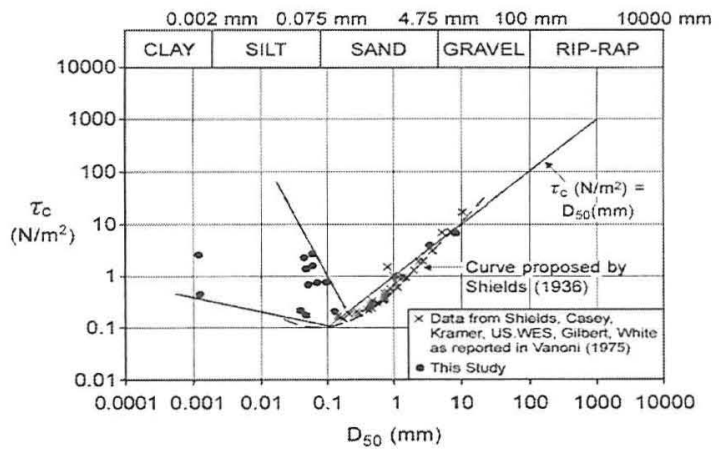

Figure 7. Quantified measure of erodibility- Critical shear stress versus mean soil grain size (From Seed et al (2006)).

Figure 8 shows that for shear stress above the threshold value for fine sand, $0.1 \mathrm{~N} / \mathrm{m}^{2}$, a significant scour rate results. For the water velocity imparted to the spillway during the failure storm, exceeding $1.0 \mathrm{~m} / \mathrm{s}$, Figure 8 indicates that fine sand in the spillway would erode at a rate exceeding $1000 \mathrm{~mm} / \mathrm{hr}$. These values apply to a bare soil not protected by vegetation. Accordingly, the values do not establish specific parameters for velocity and erosion rate applicable to the dam spillway. However, Figure 8 does provide a quantifiable indication that erosion would take place within the dam spillway during the breach storm event.
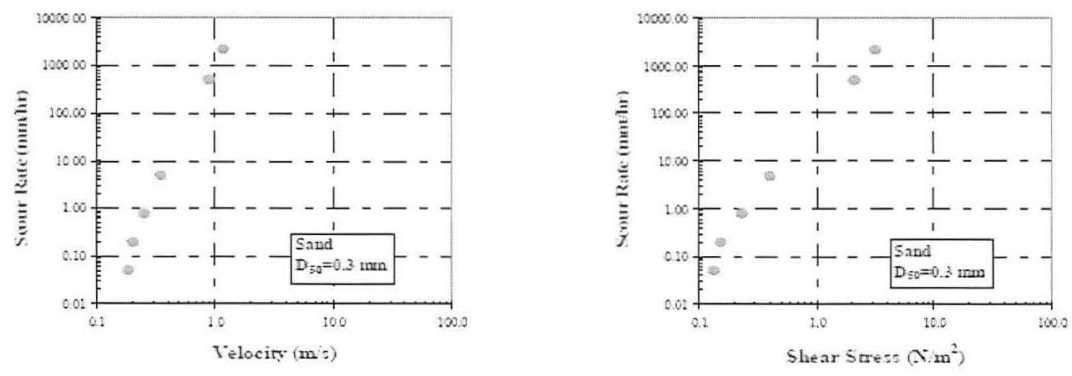

Figure 8. Erodibility function for a sand (from Seed, et. al. (2006)).

With the expected scour rate over $1000 \mathrm{~mm} / \mathrm{hr}$, and velocity imparted to the spillway exceeding $1 \mathrm{~m} / \mathrm{s}$, Figure 9 illustrates that the spillway would be highly erodible and prone to failure by overtopping. The levee study results depicted in Figures 7 through 9, combined with the sustainable velocity range portrayed in Figure 6 , explain why erosion resulted in the spillway during the breach storm event. 


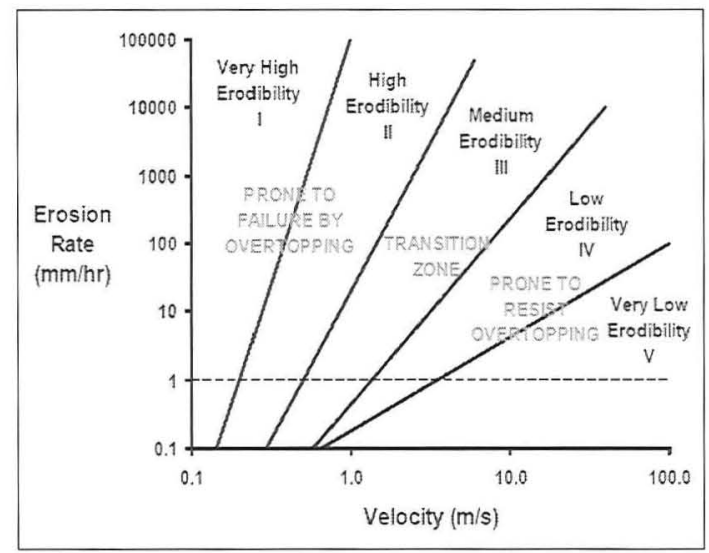

Figure 9. Proposed guidelines for levee overtopping (from Seed et. al. (2006)).

Overtopping is essentially the same erosion process that takes place in a vegetated earth spillway. This conclusion is especially true for the Archusa Creek Dam, as addressed in the DISCUSSION portion of the paper.

NRCS (1997) defines the specific process of erosion in dam earthen spillways. They describe a 3 phase process:

- The failure of the vegetal cover protection (if any) and the development of concentrated flow

- The downward and downstream erosion associated with the concentrated flow that leads to formation of a vertical or near-vertical head-cut in the vicinity of initial failure

- The upstream advance and deepening of the head-cut resulting from flow over the vertical or near vertical face

Figure 10 illustrates the process of over-topping failure in earth dams. The figure illustrates the 3 phase mechanism NRCS describes. Failure is initiated by erosion of the soil particles due to excess velocity. A near vertical face is formed, which travels progressively toward the reservoir during the erosion process (headcutting). Finally the head-cutting process effects complete breach of the dam. 

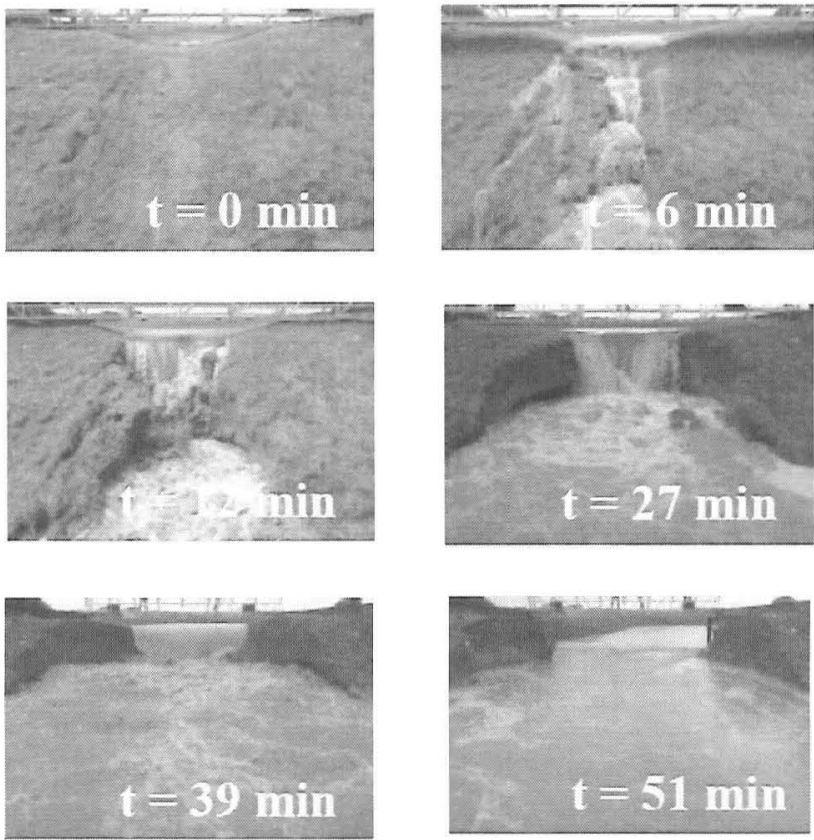

Figure 10. Illustration of dam breach by overtopping- embankment breach test of a homogeneous non-plastic sandy soil conducted at the ARS Hydraulic Laboratory, Stillwater, OK (from FEMA (2001)).

\section{DISCUSSION}

\section{Earth Spillway Design}

Established design methods call for earth spillways to be located at abutments, and founded in cut. The criterion to place the spillway in cut is to prevent erosion of fill soil. The NRCS design guide has extensive guidance for location, alignment, and grade for an emergency spillway so that erosion will not cause a breach failure, summarized below. Figure 11 illustrates design guidance for these criteria.

- Location- The most important element of location is to place the spillway where erosion and breach does not result in dam failure. As discussed above, this criterion is met by locating the spillway at an abutment, cut into native soil (alternatively the spillway can be cut through a saddle in terrain on the lake perimeter). Preferred location for the spillway is where it can discharge downstream without flow onto the toe of the dam. For sites where this alignment is impractical, training dikes can be used to keep flow off of the dam toe. But this configuration is not preferable.

- Alignment and grade- The spillway control section is designed to reduce velocity over the spillway to a sustainable level. Alignment and slope on the 
spillway are set so that velocity stays within the sustainable range for the length of the spillway.

Earthen emergency spillway design for the Archusa Creek Dam did not conform to these criteria. The spillway was not located at an abutment in cut. Rather it is located in the middle of the dam, with its bottom in fill. The spillway did not have a control section sufficient to lower velocity to a sustainable level. Further, the drainage ditch excavated into the spillway concentrated flow and increased velocity, initiating erosion during the failure storm.

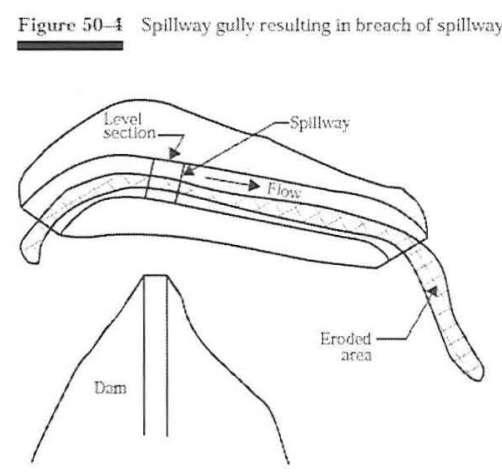

Figure11. Diagram illustrating proper emergency spillway layout (From NRCS (1997)).

With the emergency spillway not in conformance with these guidelines, erosion was a threat to dam safety. The choice of an emergency spillway lining of grass was inappropriate. Some armored lining, e.g. rip-rap would be required for the emergency spillway geometry in order to prevent erosion that could result in dam breach.

\section{Hydraulic Design}

NRCS design guides, and most state regulations, require reservoir storage and principal spillway capacity such that flow over an emergency spillway commences at a storm return period of 100 years. The 1998 configuration of the Archusa Creek Dam emergency spillway resulted in flow on near 2 year frequency.

\section{CONCLUSIONS}

For the 1998 dam configuration, the earth emergency spillway had an activation frequency of every 2 years, where this frequency by current design standards should be near 100 years. Consequently the emergency spillway was used frequently, as opposed to use on an emergency basis. For this frequency of use, the spillway should have been an armored auxiliary spillway. The Archusa Creek Dam was repaired by building a new auxiliary spillway. The main repair component was a concrete labyrinth weir spillway built within the breached area. This new concrete 
spillway is used as an auxiliary one, solving the problem of flow over an earthen emergency spillway at a 2 year frequency.

The dam breach was actually an over-topping failure. Because the earth emergency spillway is located in the interior of the dam (versus at an abutment), and built on fill (versus in cut), water flowing over this surface is essentially the same as flowing over the dam.

The case shows the merit of the NRCS design guidance for earth emergency spillways. The features identified that do not conform to the NRCS design guide were the major factors leading to failure:

- Location on the dam- not positioned at the abutment cut into native soil. The spillway was located near the center of the dam, in a position where erosion led to breach through the dam.

- Spillway surface- in fill versus cut into native soil. The use of erodible fill soil in the spillway established the speed limit for water flowing over it, roughly $0.8 \mathrm{~m} / \mathrm{s}(2.5 \mathrm{ft} / \mathrm{s})$. The $1998 \mathrm{storm}$ produced flow with velocity much greater than this limit.

- Lack of control section- no means to control velocity at the spillway entrance.

- Unsuitable lining- grass would not sustain the discharge velocity and frequency

The final conclusion pertains to addition of fish retaining grates over the principal spillway crest and sluice gate openings. Generally these grates are put over dam outlet controls to keep fish from travelling out of the lake. During the failure storm these grates clogged with debris, restricting flow through the principal spillway. The capacity lost to grates clogged with flood debris may have never been considered in the dam's operation. Use of fish retaining grates has been implicated in failures and near failures of small dams, due to diminished spillway capacity. However, any demonstrable benefit of the grates is not clearly established.

\section{REFERENCES}

FERC. (2003). "Silver Lake Dam: Root Cause Report on the May 14 $4^{\text {th }}, 2003$ Operation of the Fuse Plug Spillway and Subsequent Channel Erosion Resulting in the Uncontrolled Release of Silver Lake." FERC web-site.

FEMA. (2001). "ISSUES, RESOLUTIONS, AND RESEARCH NEEDS RELATED TO EMBANKMENT DAM FAILURE ANALYSIS.” PROC. FEMA WORKSHOP, JUNE 26-28, 2001, OKLAHOMA CITY, OK, FEMA PUBLICATION No. 541, FEMA web-site.

NRCS. (1997). "Earth Spillway Design." Chapter 50, Part 628 Dams, National Engineering Handbook, NRCS web-site.

Seed et al. (2006). "Investigation of Performance of the New Orleans Flood Protection Systems in Hurricane Katrina on August 29, 2005." National Science Foundation, University of California web-site. 